\section{Vestre Viken}

Vestre Viken HF ble etablert 1. juli 2009, da Ringerike sykehus, Drammen sykehus, Bærum sykehus og Kongsberg sykehus ble slått sammen. Lier og Blakstad psykiatriske sykehus, Hallingdal sjukestugu, 17 ambulansestasjoner og en rekke andre behandlingssteder er også del av helseforetaket.

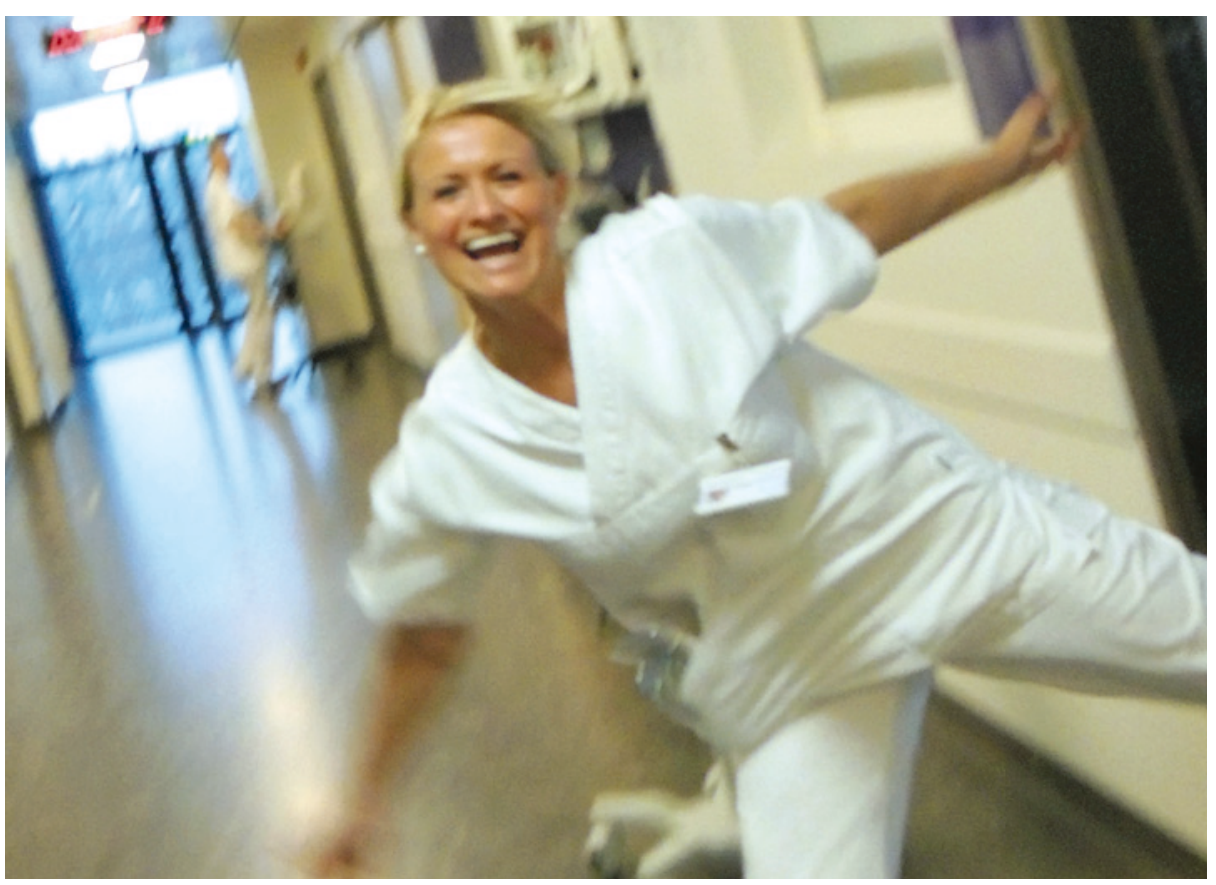

Foto: Vestre Viken

Til sammen driver foretaket sin virksomhet i 146 bygninger på til sammen mer enn 315000 kvadratmeter.

Foretaket har et samlet budsjett på nærmere 7,5 milliarder kroner. Vi har over 9500 ansatte og samarbeider tett med primærhelsetjenesten i kommunene for å levere sykehus- og spesialisthelsetjenester til 465000 mennesker i 26 kommuner. Hvert år fødes det over 5000 barn hos oss. Vi har ca. 375000 somatiske og over 200000 psykiatriske pasienter til behandling årlig, med over 575000 somatiske konsultasjoner, 330000 bildediagnostiske undersøkelser og 365000 kirurgiske inngrep hvert år.

Vestre Viken har som mål å levere gode, trygge og likeverdige helsetjenester til alle som trenger det når de trenger det. Foretaket er en solid arbeidsplass, med mye variasjon og flere forskjellige arbeidslokaliteter. Noen av de største arbeidsplassene våre er Klinikk for psykisk helse og rus, Drammen sykehus, Bærum sykehus, Ringerike sykehus og Kongsberg sykehus. I tillegg skal det bygges et nytt og større områdesykehus i Buskerud.

Psykisk helse og rus er den største klinikken i Vestre Viken. Den har et av Norges mest komplette tilbud innen fagfeltet. Bcerum sykehus og Drammen sykehus er spesialsykehus som i hovedsak behandler pasienter med somatiske lidelser. Drammen sykehus er det største somatiske sykehuset i Vestre Viken. Ringerike sykehus er et lokalsykehus med akuttfunksjon og et stort ansvarsområde i Buskerud. Kongsberg sykehus er lokalsykehus og samarbeider tett med kommunene for å levere et robust og fremtidsrettet helsetilbud til befolkningen. www.legejobber.no

'09.03.

FRIST FOR REGISTRERING AV ANNONSER TIL NR. 6/2015

PÅ LEGEJOBBER.NO

\section{Om Legejobber.no}

Legejobber.no er Tidsskriftets stillingsportal for leger og for stillingsannonsører.

Som annonsør kan du nå bestille annonsen døgnet rundt via Legejobber.no. Du registrerer nettannonsen og papirannonsen samtidig.

\section{Som jobbsøker kan du på}

Legejobber.no enkelt søke etter ledige jobber etter spesialitet, geografisk område eller i fritekst.

Ønsker du å motta varsel om ledige stillinger innenfor et bestemt område?

På Legejobber.no kan du abonnere på ledige stillinger.

\section{Priser på stillingsannonser 2015}

* Gjelder for kombinasjon papir/nett.

$\begin{array}{lr}\text { Format } & \text { Størrelse } \\ 1 / 1 \text { side } & 185 \times 245 \\ \text { Pris svart-hvitt } & 32200 \\ \text { Pris 4 farger } & 35400 \\ 1 / 2 \text { s. liggende } & 185 \times 112 \\ \text { Pris svart-hvitt } & 17300 \\ \text { Pris 4 farger } & 20400 \\ 1 / 2 \text { s. stående } & 90 \times 245 \\ \text { Pris svart-hvitt } & 17300 \\ \text { Pris 4 farger } & 20400 \\ 1 / 4 \text { side } & 90 \times 112 \\ \text { Pris svart-hvitt } & 9200 \\ \text { Pris 4 farger } & 11200 \\ \text { 1/8 side } & 90 \times 45 \\ \text { Pris svart-hvitt } & 7000 \\ \text { Pris 4 farger } & 8000\end{array}$

